\title{
Occupational Fraud in Micro-Financial Institutions in Cameroon: Strategies for Timely Detection and Control
}

\author{
Samuel T. MUKAH ${ }^{1}$ \\ ${ }^{1}$ Department of Accountancy, Faculty of Economics and Management Sciences, University of Bamenda, \\ Cameroon \\ Correspondence: Samuel Tanjeh Mukah (CFIP, Ph.D.), Department of Accountancy, Faculty of Economics and \\ Management Sciences, University of Bamenda, P.O. Box 39 Bambili, Cameroon. Tel: 237-677-383-633. E-mail: \\ sammukah2003@yahoo.com
}

Received: April 23, 2020; Accepted: May 5, 2020; Published: May 19, 2020

\begin{abstract}
Occupational fraud has persistently become a hurtful problem in micro-financial institutions (MFIs) in Cameroon. Staff and management of some MFIs are suspended, terminated, or litigated after they are suspected of involvement in occupational fraud over the years. Such delayed detections have caused huge losses to the organisations. In this respect, a study was conducted to examine strategies for timely detection and control of occupational fraud in MFIs in Cameroon. A simple random sampling was carried out to obtain 110 certified fraud examiners and auditors who have had the opportunity to audit or examine micro financial institutions in Cameroon from 2013 to 2019. They gave their experiences of strategies for timely occupational fraud detection and control in micro-financial institutions in Cameroon. The data generated was analysed, regressed, and interpreted. The empirical results disclosed that for MFIs in Cameroon to timely detect and control occupation fraud: they need to carry out frequent monitoring and surprise audits, institute tips and notifications, not rely on discovering occupational fraud through accidents and/or confessions and lastly, not to place reliance on information technology control and surveillance because the facilities that support their operation in Cameroon are poorly developed and greatly politicised.
\end{abstract}

Keywords: occupational fraud, detection and control strategies, microfinance

\section{Introduction}

\subsection{Problem and its Importance}

Public awareness about the shocking consequences of occupational fraud in both private and public establishments has multiplied the interest that organisations have to timely detect fraud and nip it in the bud. Occupational fraud is defined by the Association of Certified Fraud Examiners (ACFE, 2018) as "the use of one's occupation for personal enrichment through the deliberate misuse or misapplication of the employing organisation's resources or assets". It is a type of fraud committed against the organisation from within. That is, by the very people entrusted with the responsibility of protecting and managing the resources of the organisation such as the managers, directors, and employees.

Occupational fraud has remained a persistently predominant and upsetting problem in Cameroon. Cameroon is a country located on the Gulf of Guinea. It is sometimes identified as either a West African country or a Central African country because of its strategic location at the intersections between West and Central Africa. With some 240 native languages, and a population of close to 24 million people, Cameroon has French and English as its official languages. Yaounde is its political capital, and Douala its economic capital. Every organisation in the world in general, and in Cameroon in particular is either vulnerable or potentially vulnerable to fraud carried out by its workers. Most of the time, the damage caused to the entity is quite enormous and irreparable. Fraud always involves efforts at covering-up. As a result many fraud cases go partially or fully unnoticed, and the precise magnitude of losses are difficult to quantify (Seetharaman, et al. 2004). In this regard, it can only be reasonably estimated to quantify the losses (ACFE, 2012).

Fraud involves deceit or trickery or false representation that leads to intentional concealment of truth in order to induce another to part with something of value, or to surrender a legal right [International Standards on Auditing (ISA) 240]. Occupational fraud also called internal fraud is the use of one's occupation for personal enrichment through the deliberate misuse or misapplication of the employing organisation's resources or assets (ACFE, 2012). 
In a nutshell, occupational fraud comprises fraud involving management and employees of the entity. Collusion within the entity or with third parties outside of the entity usually expedite the illicit practice. Occupational fraud results in either calculated misappropriation of assets, corruption, and/or distortion of financial statements, for the benefit of the perpetrator at the injury of someone, some organisation, or the public.

The 2018 Report to the Nations by ACFE (2018) was based on 2,690 cases of occupational fraud reported from 125 countries. The report disclosed that occupational fraud has a colossal impact on organisations throughout the world. With this in mind, and given that some micro-financial institutions in Cameroon during their general assembly meetings complain about suspected occupational fraud practices that have plunged their organisations into colossal financial losses over the years, the researcher developed interest to investigate timely detection schemes and controls to curb this recurrent situation.

To successfully explore these areas the following research questions were designed:

i. What are the occupational fraud detection schemes in micro financial institutions in Cameroon?

ii. What are the occupational fraud control schemes in micro financial institutions in Cameroon?

Consequently, the objectives were to:

i. Investigate the occupational fraud detection schemes in micro financial institutions in Cameroon.

ii. Examine the occupational fraud control schemes in micro financial institutions in Cameroon.

\subsection{Relevant Scholarship}

The occupational fraud related concepts reviewed are: management fraud, employee fraud, asset misappropriation fraud, financial statement fraud, internal control system, corruption, and microfinance.

Occupational fraud occurs when one or more individuals in a management position, those charged with governance, employees, or third parties, intentionally act by involving the use of deception to obtain an unjust or illegal advantage. Management fraud involves one or more members of management while employee fraud involves only employees of the organisation (ISA 240).

Financial statement fraud occurs when there is deliberate misrepresentation in the financial statement of an organisation in order to deceive users. Such a misstatement is considered material when it influences the economic decisions taken by the users (Accounting Tools, 2018). The primary responsibility for prevention and detection of irregularities and errors in an organisation rests with management because it has a contractual duty of care for the assets of the owners. Consequently, it is management's responsibility to set up an internal control system. That is, a system of controls set up by the management of a company to carry out the business of the company in an orderly and efficient manner. Such a system ensures the adherence to management policies, safeguard of assets, completeness and accuracy of the assets of the company's activities. An internal control system is composed of many individual internal controls (Oxford Dictionary of Accounting, 2010).

According to the ACFE (2018) occupational fraud committed could be either asset misappropriation fraud, financial statement fraud, and/or corruption fraud. Misappropriation of assets involves stealing of an entity's assets and is often committed by employees in relatively small and immaterial amounts. In some cases, management too is involved and with the means at its disposal it easily conceals the fraud. Occupational fraud can be committed by company directors or persons entrusted to hold and manage the assets in the interests of an organisation or its employees. Misappropriation of assets can be accomplished by embezzling receipts, creating false invoices, making false expense claims, stealing data and intellectual property, causing an entity to pay for goods and services not received, and using an entity's assets for personal use (ISA 240). For example, using the entity's assets as collateral for a personal loan. Misappropriation of assets also includes diversion of payments or creating fictitious or ghost employees, or an employee exaggerating the qualification and getting a job that pays according to the fake qualification.

Corruption fraud also plays a significant role in upholding occupational fraud. Section 134 of the Cameroon Penal Code considers any employee who for himself or for a third party solicits, accepts or receives any offer, promise, gift or present in order to perform, refrain from performing or postpone any act of his office to have carried out corruption. Corruption is "an immoral and unethical phenomenon that contains a set of moral aberrations from moral standards of society, causing loss of respect and confidence in duly constituted authority" (Gould, 1991). Corruption includes giving or accepting bribes or inappropriate gifts, double dealing, under-the-table transactions, manipulating elections, diverting funds, laundering money and defrauding. Center for Responsibility Enterprise and Trade (2018) asserts that corruption threatens a company's potential or survival in numerous ways that may lead to significant business disruption, financial toll, legal implications, and negative impact on the reputation of an organisation. 
Transparency International (2019) sees corruption as the abuse of entrusted power for private gain. Depending on the level of loss involved and the sector where it occurs corruption can be classified as grand, petty, and political. Corruption and crime are endemic sociological occurrences which appear with regular frequency in virtually all countries on a global scale and in varying degree and proportion. The 2019 Corruption Perceptions Index asserts that big money in political campaigns and lack of inclusive political decision-making, perpetuate corruption. This assertion applies fully to Cameroon where during the 2020 legislative and municipal elections there was a lot of big money thrown around.

Kelly (2015) proffers that Cameroon still faces multiple challenges in its effort to curb corruption due to insincerity and lack of political will on the side of the government. According to him corruption abounds in the customs, police, judicial system, public procurement and contracting, environment, and natural resources and extractive industry.

Article 1 of 2002 law n ${ }^{\circ}$ 01/02/CEMAC/IMAC/COBAC governing microfinance institutions in the CEMAC region describes microfinance as "activities undertaken by authorised entities that are neither banks nor financial institutions but take savings or deposits, give out credits or loans..." Microfinance is classified into 3. Category one MFIs institutions such as associations, cooperatives and credit unions collect savings and deposits and lend solely to their members. Category two financial institutions such as limited liability companies that function more like micro-banks, collect savings and deposits and lend them to non-members. Unlike category 1 institutions with no clear definition of capital, they have a minimum capital of 50 million F.CFA. Category 3 MFIs are lending institutions such as micro credit and project finance institutions that do not collect savings and deposits but give out loans. They have a minimum capital of 25 million F.CFA (COBAC, 2002).

The theories of fraud triangle, fraud diamond, fraud pentagon, agency, differential association, and social control, were reviewed as related to occupational fraud. The fraud triangle theory was introduced in 1953, by Donald Cressey in the study of fraud. He contended that everything people do is motivated by something (Abdullahi et al., 2015). Driven by why people commit fraud Cressey carried out a study in which 200 embezzlers imprisoned served as participants. His findings disclosed that every fraud had 3 things in common: pressure, rationalisation, and opportunity to commit the fraud. According to him it is pressure that emanates from insatiable greed, bad habits, and psychosis that motivates management and staff to commit occupational fraud. Fraud opportunities come up when the internal control system develops weaknesses known to the perpetuators. Motivation and opportunities are interactive. As a consequence, the less the known weaknesses in the internal controls, the less the motivation needed to carry out a fraud and vice versa.

The fraud diamond theory introduced by Wolfe and Hermanson (2004) is seen as an extension of the fraud triangle theory. In addition to the elements of the fraud triangle namely pressure, opportunity, and rationalisation, Wolfe and Hermanson (2004) introduced a fourth element called capability. The authors contend that without the capability to recognise the uncluttered entranceway as an opportunity and to take advantage to commit the fraud, even with the existence of the 3 elements in the fraud triangle, fraud will not be possible (Sorunke, 2016 and Tugas, 2012).

The pentagon fraud theory by Crowe adds one element called arrogance to the diamond theory which had initially added one to the fraud triangle theory called capacity or capability discussed earlier. Crowe (2011) asserts that chief executive officers possess a large ego, a bullying attitude, and an autocratic management style. These physiognomies enable them undermine internal controls and perpetuate fraud with impunity. These CEOs always fear the loss of position or status so protect it at all cost (Marsellisa, 2018).

Another theory related to occupational fraud is agency theory. It demonstrates the relationship between two parties where one party acts on behalf of the other, although the two parties (principal and agent) have dissimilar interests and unequal access to information. This relationship generally results in an agency dilemma, where it becomes difficult to implore the agent to act in the best interests of the principal (Lucian and Jesse, 2004; Guangdi and Fulwood, 2013).

The theory of differential association by Edwin Sutherland in 1939 and revised in 1947 contends that criminal behaviour is learned through interaction with other persons in the course of communication, and intimate social groups (Vinney, 2019). By interacting with others, individuals learn the values, attitudes and techniques, and motives for criminal behaviour. By this assertion, criminal behaviour may not just be explained through needs and values as seen in the fraud triangle and diamond theories. On the other hand, the social control theory argues that the institutions of the social system train and pressurise those with whom they interact into patterns of conformity (ACFE, 2016). This implies that if the institutions are corrupt, persons interacting with them will be brainwashed and compelled to comply, or be seen as 'breaking the law'. 
The findings of a research carried out by Norman Jaspan and published in 1960 revealed that for organisations to avoid employee fraud, theft and embezzlement, they must have to pay their staff fairly well, treat them decently, and give a listening ear to their problems. In discordant with Norman's generalities, Hartung insisted that fraud is learned from the environment. According to Singleton (2010), the two submissions go together given that Norman (1960), disclosed that for organisations to avoid employee fraud, theft and embezzlement, they need to pay their employees fairly, cultivate a listening ear to their problems, and treat them decorously although not placing full confidence on them. An environment with many reasons and opportunities to commit fraud will irrefutably nurture fraud.

Rahmana and Anwar (2014) in examining the effectiveness of the techniques of preventing and detecting fraud in Malaysian Islamic banks, disclosed that fraud will always occur no matter how much effort an organisation makes in discouraging and controlling fraud. They resolved that education of employees on fraud avoidance and detection practices was a praiseworthy solution for fraud. They suggested some measures to be simultaneously performed in order to mitigate fraud namely: dissuasion, prevention, detection, mitigation, analysis, policy, investigation and prosecution.

A report to the nations on the 2018 global study on occupational fraud and abuse by the Association of Certified Fraud Examiners ACFE (2018) disclosed that 2,690 real cases of occupational fraud recorded in 125 countries were analysed. The study conducted between January 2016 and October 2017. The data presented was drawn from Certified Fraud Examiners who investigated those cases. In 23 categories of industries, occupational fraud caused a total loss of $\$ 7$ billion. Asset misappropriation fraud was at the top (89\%) with a median loss of $\$ 114,000$. Financial statement fraud although the least as it affected only $10 \%$ of the cases, was the most costly with a median loss of $\$ 800,000$. Small businesses lost almost twice as much per fraud scheme, $\$ 104,000$ median loss.

The 2018 report to the nations identified tips as the most common initial detection method (40\%), followed by internal audit (15\%), and management review (13\%). Internal control weaknesses contributed to almost half of the frauds. Interestingly, 18 anti-fraud controls examined allied with lower fraud losses and quicker detection. Owners and executives account for a small percent of cases (19\%), yet caused a significant median loss of $\$ 850,000$. Men caused more losses (75\%) than women. Median losses are far greater when fraudsters collude: 1 fraudster $\$ 74,000$, 2 fraudsters $\$ 150,000$, and 3 fraudsters $\$ 339,000$.

Furthermore, the report disclosed that data monitoring/analysis and surprise audits were associated with the largest reduction in fraud and loss duration. Unfortunately, only $37 \%$ of victim organisations applied these controls. Over the last 10 years, occupational fraud referrals to prosecution declined by $16 \%$ for fear of negative publicity. Fraudsters who had been with their company longer stole twice as much: $\$ 200,000$ median loss for those who have worked for more than 5 years, and $\$ 100,000$ for those less than one year. Only $4 \%$ of proprietors had a prior fraud conviction.

According to the ACFE (2018) occupational fraud committed could be put in 3 categories namely: asset misappropriation, financial statement fraud, and corruption. The most common of these $88 \%$ was asset misappropriation, though the least costly, causing a median loss of USD 100,000. Financial statement fraud schemes accounted for $6 \%$ of government fraud cases and had a median loss of USD 315,000. Corruption schemes occurred in $47 \%$ of cases and caused a median loss of USD 400,000. Corruption in government cases had a significantly high frequency and median loss in the overall survey data. This confirms the public sector to have the highest risk of occupational fraud. In general, actions taken against perpetrators range from termination, settlement agreement, permitted or required resignation, probation or suspension, to no punishment at all.

A study was carried out amongst Jordanian companies listed on the ASE by Shanikat, Al-Farah, and Dorgham (2014) to examine the effectiveness of occupational fraud prevention mechanisms in these companies. The results showed that management review of the internal control, internal and external audits are greatly and successfully implemented in all the organisations examined. Code of conduct, independent audit committees and surprise audits were ranked high in these companies, while mechanisms such as specialist or professional risk assessments and rewards for whistle blowing seem not applicable in Jordanian companies.

\section{Method}

A simple random sampling was carried out to obtain 110 certified fraud examiners and auditors who have had the opportunity to audit or examine micro financial institutions in Cameroon from 2013 to 2019. In an online survey the participants gave their experiences of strategies for timely occupational fraud detection and control in microfinancial institutions during this period. 103 respondents (or 93.65\%) successfully responded to the questionnaire. In a Likert scale the items examined were rated from 1 to 5 , where: (5) = very strong, (4) = strong, (3) = fairly 
strong, $(2)=$ weak and (1) = very weak. The respondents rated each parameter under examination according to the degree of perception they have.

A regression analysis was run with the aim of generating a regression output that was used in determining the effect of independent variables on the dependent variable. The study employed the multiple regression models shown below. The indicators of Occupational fraud detection schemes (OFDS) were: management review and internal audit (MSA), Fair treatment of staff (FTS), tips and notifications (TN), rotation of duties and abrogation of paid leave (RDAPL), information technology control and surveillance (ITCS), and accidents and confession (AC).

$$
\text { Occupational fraud detection schemes }=\mathrm{f} \text { (Fraud Control Experience) }
$$

From equation (1) above, it was considered that Fraud Control Experience will be broken into sub components as seen in equation (2) below:

$$
\text { OFDS }=\mathrm{f}(\text { MSA, FTS, TN, RDAPL, ITCS and AC) }
$$

Considering the importance of the intersect coefficients to be estimated and error term, the econometrics equation for the model becomes:

$$
\mathrm{OFDS}=\beta_{0}+\beta_{1} \mathrm{MSA}+\beta_{2} \mathrm{FTS}+\beta_{3} \mathrm{TN}+\beta_{4} \mathrm{RDAPL}+\beta_{5} \mathrm{ITCS}+\beta_{6} \mathrm{AC}+\varepsilon \mathrm{i}
$$

Where:

$$
\begin{array}{ll}
\text { OFDS } & =\text { Occupational fraud detection schemes } \\
\text { MSA } & =\text { Monitoring and surprise audits } \\
\text { FTS } & =\text { Fair treatment of staff } \\
\text { TN } & =\text { Tips and notifications } \\
\text { RDAPL } & =\text { Rotation of duty and abrogation of paid leave } \\
\text { ITCS } & =\text { Information technology control and surveillance } \\
\text { AC } & =\text { Accidents and confessions } \\
\beta_{0} & =\text { Intersect, } \beta_{1}, \beta_{2}, \beta_{3}, \beta_{4}, \beta_{5} \text { and } \beta_{6} \text { are the coefficients to be estimated } \\
\mathrm{Ei} & =\text { Error term }
\end{array}
$$

\section{Results}

Appendix 1 shows that $41 \%$ of the respondents have experience in occupational fraud detection scheme measures for 5 to 10 years. $37 \%$ of them have gotten experience in occupational fraud detection scheme measures for more than 10 years. So there were about $80 \%$ of the respondents who were well experienced in occupational fraud detection scheme measures. Appendix 2 presents the perceptions of the respondents on initial detection of occupational fraud.

Table 1. Summary of descriptive statistics

\begin{tabular}{llllll}
\hline Variable & Obs & Mean & Std. Dev. & Min & Max \\
\hline OFDS & 103 & 3.029126 & 0.9747429 & 1 & 4 \\
MSA & 103 & 8.097087 & 1.346852 & 4 & 10 \\
FTS & 103 & 3.23301 & 1.541605 & 1 & 5 \\
TN & 102 & 5.637255 & 1.440498 & 3 & 10 \\
RDAPL & 101 & 7.871287 & 1.604141 & 4 & 10 \\
ITCS & 103 & 8.165049 & 1.442337 & 3 & 10 \\
AC & 103 & 5.932039 & 2.397965 & 2 & 10 \\
\hline
\end{tabular}

The summary of descriptive statistics are presented in table 1. It shows that most of the variables are having 103 observations each. Also, the table above can be used as a prelude to test for normality. The average values of all the variables are greater than their standard deviations. This implies that the variables are normally distributed, making the model credible. 
Table 2. Pairwise correlation matrix

\begin{tabular}{lcllllll}
\hline & OFDS & MRIA & EA & TN & DEAR & ITCS & AC \\
\hline OFDS & 1 & & & & & & \\
MSA & 0.1248 & 1 & & & & & \\
FTS & -0.0568 & -0.1102 & 1 & & & & \\
TN & 0.1320 & 0.1540 & $0.2321^{* *}$ & 1 & & & \\
RDAPL & 0.0287 & $0.1907^{*}$ & $-0.3258^{* * *}$ & -0.0669 & 1 & & \\
ITCS & $-0.1917^{*}$ & 0.0068 & 0.1192 & 0.0988 & -0.0120 & 1 & \\
AC & -0.0746 & $0.3360^{* * *}$ & -0.1495 & 0.1395 & 0.1234 & $-0.1781^{*}$ & 1 \\
\hline$* * * \mathrm{p}<0.01, * * \mathrm{p}<0.05, * \mathrm{p}<0.1$ & & & & & &
\end{tabular}

The correlation results presented in table 2 show that there exist both positive and negative relationships between the variables involved in the study. These results also show that the correlation between one variable and itself is 1, (perfectly collinear). The correlation results could also be used as a prelude to investigate the presence of multicollinearity. All these values again lie between the bench mark values of -0.75 and 0.75 , which indicate that there is no problem of multicollinearity among these variables.

Table 3. Test for Heteroskedasticity

\begin{tabular}{l}
\hline Breusch-Pagan / Cook-Weisberg test for heteroskedasticity \\
\hline Ho: Constant variance \\
Variables: fitted values of OFDS \\
chi2(1) $=13.83$ \\
Prob $>$ chi $2=0.0002$ \\
\hline
\end{tabular}

To test for heteroskedasticity, the Breusch-Pagan/Cook-Weisberg test was used. The decision rule is that, when $\mathrm{BP}_{\text {cal }}>\mathrm{BP}_{\text {cri, }}$, we talk of homoscedasticity. Therefore, from table $3 \mathrm{Prob}>\mathrm{chi}^{2}=0.0002$, we fail to reject $\mathrm{H}_{0}$, and conclude that there is constant variance. Hence no problem of heteroscedasticity exists in the obtained results.

Table 4. Regression results

\begin{tabular}{llll}
\hline OFDS & Coef. & (Std. Err.) & $\mathrm{P}>|\mathrm{t}|$ \\
\hline MSA & 0.1271 & $(0.0761)$ & 0.098 \\
FTS & -0.0601 & $(0.0667)$ & 0.369 \\
TN & 0.1680 & $(0.0718)$ & 0.021 \\
RDAPL & 0.0133 & $(0.0629)$ & 0.833 \\
ITCS & -0.1739 & $(0.0664)$ & 0.010 \\
AC & -0.0943 & $(0.0427)$ & 0.030 \\
Cons. & 3.1316 & $(0.9564)$ & 0.001 \\
\hline Number of obs $=103$ & & \\
F $(6,93)=2.58$ & \\
Prob $>$ F $=0.0234$ & & \\
Adj R-squared $=0.875$ & & \\
\hline
\end{tabular}

\section{Discussion}

From the regression results presented in table 4 it can be clearly deduced that the value for $F_{\text {cal }}(6,93)>P(0.0234)$. We reject $\mathrm{H}_{0}$, and conclude that the independent variables have significant effects on the dependent variable (OFDS), and this is statistically significant at the $10 \%$ level of significance. Thus, the overall model is well fitted.

The value for Adjusted $\mathrm{R}^{2}$ indicates the degree of variations in OFDS captured by variations in the variables used in the model. From the result in table 4, the value of Adjusted $\mathrm{R}^{2}$ is 0.875 indicating that $87.5 \%$ variation in OFDS is attributed to changes (variations) in the variables included in the model while $12.5 \%$ variations in OFDS is caused by variables not included in the model. The coefficient of the constant 3.1316 indicates the intersect, which implies that if all the independent variables under study were considered to be zero or not to have any effect on the dependent variable (OFDS), then OFDS will be 3.1316 in the model. 
The coefficient of monitoring and surprise audits (MSA) is positive, indicating a positive relationship between MSA and OFDS. The MSA coefficient of 0.1271 indicates that an increase in MSA by a unit will lead to an increase in OFDS by 0.1271 . This result is statistically significant at $10 \%$ level. It agrees with the results of the study carried out amongst Jordanian companies listed on the ASE by Shanikat, Al-Farah, and Dorgham (2014).

Management review and internal audits are very effective occupational fraud prevention mechanisms. The result is also in line with the 2018 report to the nations by ACFE which revealed that data monitoring/analysis and surprise audits were associated with the largest reduction in fraud and loss duration. Apart of the fact that they deter occupational fraud, the process allows management to easily identify and correct any internal control weaknesses that could create opportunities for fraud.

The coefficient of tips and notification (TN) is also positive indicating a positive relationship between TN and OFDS. The TN coefficient of 0.1680 indicates that an increase in TN by a unit will lead to an increase in OFDS by 0.1680 . This result is statistically significant at $5 \%$ level. It is very important for organisations to put a price tag for whistle blowing, tips and notifications from both the internal and external stakeholders. In this way occupational fraud can easily be detected and put under control. The result is in consonance with one of the results of the 2018 report to the nations which identified tips as the most common initial detection method constituting $40 \%$ of the detection methods (ACFE, 2018).

The coefficient of information technology control and surveillance (ITCS) is negative indicating a negative relationship between ITCS and OFDS. The ITCS coefficient of -0.1739 indicates that an increase in ITCS by a unit, will lead to a decrease in OFDS by 0.1739 . This effect is statistically significant at $5 \%$ level. This could be attributed to the fact that facilities that cause ITCS to thrive in Cameroon such as uninterrupted internet and electricity supplies are still very poorly developed. Sometimes the Cameroon government deliberately cuts off these facilities in order to grabble with its own internal security challenges. This happens quite often in the North West and South West Regions of the country where since 2017 armed conflicts between 'restorationists' (called Ambazonians) and government forces escalated with very severe human rights abuses.

Furthermore, the coefficient of accidents and confessions (AC) is also negative indicating a negative relationship between AC and OFDS. The AC coefficient of -0.0943 indicates that an increase in AC by a unit, this will lead to a decrease in OFDS by 0.0943 . This effect is statistically significant at $5 \%$ level. This tells us that organisations that wait for fraud to be disclosed accidentally, or fraudsters to confess their sins may never detect any occupational fraud. Rather, more productive strategies should be put in place to curb occupational fraud.

\section{Policy Recommendations and Conclusion}

This study reveals the strategies for occupational fraud detection and control in micro-financial institutions in Cameroon. They are recommended to be used by microfinance institutions themselves, regulatory authorities, supervisors, anti-money laundering and fraud officials.

The first one is that monitoring and surprise audits should be applied frequently. This is a very effective occupational fraud prevention strategy associated with significant reduction in fraud and loss duration. This technique has a deterrent effect on the perpetuation of occupational fraud since potential fraudsters are not aware of when the stratagem can be executed. Because of this uncertainty committing the fraud and concealing it before monitoring and surprise audits take place, many potential occupational frauds can be significantly avoided.

The second recommendation is that tips and notifications be they from law enforcement officers or other interested parties should be greatly promoted because they facilitate occupational fraud detection and prevention. MFIs should pay attention to behavioural red flags, and make public that whistle blowers, tipsters, and informants of suspected occupational fraud will be highly compensated and their identities undisclosed. With such a price tag, most management and staff will be deterred from engaging in fraudulent activities knowing that colleagues and the public are on the alert to report suspects and pick up prizes. This should be the commonest initial detection method that MFIs can embrace and implement.

The third recommendation is that MFIs in Cameroon should not place much reliance on information technology control and surveillance as a strategy to timely detect and control occupational fraud because of the poor development and politicisation of facilities that support their operation especially electricity and internet supplies. In Cameroon, electricity and internet supplies are interrupted either deliberately or inadvertently on daily basis even in the political, economic, and regional capitals of the country.

Fourthly MFIs in Cameroon should never hope to discover an occupational fraud through an accident and/or a confession. The organisation should rather develop more productive strategies to curb occupational fraud bearing 
in mind that unless workers are educated on professional code of ethics and preached the Gospel of repentance or instant death, it is unexpected that a confession can be given by a culprit.

MFIs should treat their workers fairly and still have in mind that the best of salaries and other working conditions may reduce occupational fraud but will never exterminate it. Some frauds are committed by management and staff suffering from insatiable greed and/or psychosis. The best way out of such a situation is to apply all the above strategies simultaneously.

In conclusion, no organisation in the world is completely free from occupational fraud. Consequently, every MFI in Cameroon should put in place sound internal control systems and adopt and implement the four strategies recommended in this study in order to ensure timely detection and control of occupational fraud before it inflicts heavy losses on the entity.

\section{Acknowledgement}

I acknowledge with gratitude receipt of a research grant from the Cameroon Ministry of Higher Education (MINESUP).

\section{References}

Abdullahi, R., Mansor N., \& Nuhu, M. S. (2015). Fraud Triangle Theory and Fraud Diamond Theory: Understanding the Convergent and Divergent for Future Research. European Journal of Business and Management, $\quad 7(28), \quad 2015 . \quad$ ISSN 2222-1905 (Paper) ISSN 2222-2839 (Online). https://doi.org/10.6007/IJARAFMS/v5-i4/1823

Association of Certified Fraud Examiners Inc. (2018). Report to the Nations, global study on occupational fraud and abuse. Retrieved from https://www.acfe.com/uploadedFiles/ACFE_Website/Content/rttn/2018/ RTTNAsia-Pacific-Edition.pdf

Association of Certified Fraud Examiners. (2008). Fraud examination and forensic accounting services. Retrieved July 2019 from http://www.forensicinvspec.com/

Association of Certified Fraud Examiners. (2010). Report to the Nation on Occupational Fraud. Retrieved July, 2018, from https://acfe.com/ documents/2010RttN.pdf

Association of Certified Fraud Examiners. (2012). Report to the Nations on Occupational Fraud and Abuse, Retrieved from http://www.acfe.com/uploadedFiles/ACFE_Website/Content/rttn/2012-report-to-nations.pdf

Center for Responsibility Enterprise and Trade. (2018). Retrieved from https://create.org/news/the-consequencesof-corruption/

COBAC. (2002). Règlement $\mathrm{N}^{\circ}$ 01/02/CEMAC/IMAC/COBAC relatif aux Conditions d'Exercice et de Contrôle de l'Activité de Microfinance dans la Communauté Economique et Monétaire d'Afrique Centrale.

Cressey, D. R. (1953). Other people's money. A study of the social psychology of embezzlement. New York, NY, US: Free Press.

Crowe, H. (2011). Why the Fraud Triangle is No Longer Enough. Retrieved December 2019 from https://www.crowehorwath.com

Gould, D. J. (1991). Administrative corruption: incidence, causes, and remedial strategies. In: Farazmand A (ed). Handb Comp Dev Public Admin, p. 467-480.

Guangdi, C., \& Fulwood, C. (2013). An Agency Theory Approach to Sovereign Debt Crisis. The International Journal of Business and Finance Research, 7(5), 123-134.

Gujarati, D. (2004): Basic Econometrics. McGraw-Hill Companies, New York. International Standards on Auditing (ISA) 240 Summary: The auditor's responsibilities relating to fraud in an audit of financial statements. Retrieved from http://leaccountant.com/2014/08/02/isa-240-summary

Kathleen, M. E. (1989). Agency theory: An assessment and Review. The Academy of management Review, 14. https://doi.org/10.2307/258191

Kelly M. A. (2015). Fraud and Corruption Practices in Public Sector: The Cameroon Experience. Research Journal of Finance and Accounting, 6(4). Retrieved from http://www.iiste.org

Lucian, B., \& Jessie F. (2004): Pay without Performance: The Unfulfilled Promise of Executive Compensation. Cambridge: Harvard University Press.

Marsellisa, N. (2018). Financial statement fraud: Perspective of the Pentagon fraud model in Indonesia. Academy 
of Accounting and Financial Studies Journal, 22(3).

Nenyiaba, I. C., \& Okoye E. I. (2015). Evaluation of Key Determinants of Fraud Free Financial Report: A Focus on Nigeria. Business and Management Studies, 1(2). https://doi.org/10.11114/bms.v1i2.819

Norman, J. (1960). The thief in the white collar. Retrieved July 2018 from https://www.abebooks.co.uk/book-search/title/the-thief-in-the-white-collar/author/norman-jaspan

Oxford Dictionary of Accounting. (2010). Oxford University Press. Retrieved from http://www.oup.com

Rahman, R. A., \& Anwar, I. S. K. (2014). Effectiveness of fraud prevention and detection techniques in Malaysian Islamic banks. Procedia - Social and Behavioral Sciences, 145(2014), 97-102. https://doi.org/10.1016/j.sbspro.2014.06.015

Seetharaman, A., Senthilvelmurugan, M., \& Periyanayagam, R. (2004). Anatomy of computer accounting frauds. Managerial Auditing Journal, 19(8), 1055-1072. https://doi.org/10.1108/02686900410557953

Shanikat, M., Al-Farah, A., \& Dorgham, T. H. (2014). Occupational Fraud Prevention Mechanisms: Jordanian Companies Experience. Research Journal of Finance and Accounting, 5(1). Retrieved from $\mathrm{http}: / / \mathrm{www}$. iiste.org

Singleton, T. W. (2010). Fraud Auditing and Forensic Accounting. Retrieved November 2018 from https://books.google.cm/books?isbn=047056413X

Sorunke, O. A. (2016). Personal Ethics and Fraudster Motivation: The Missing Link in Fraud Triangle and Fraud Diamond Theories. International Journal of Academic Research in Business and Social Sciences, 6(2). https://doi.org/10.6007/IJARBSS/v6-i2/2020

Transparency International. (2019). What is corruption? Retrieved from https://www.transparency.org/what-iscorruption

Tugas, F. C. (2012). Exploring a new element of fraud: A study on selected financial accounting fraud cases in the world. American International Journal of Contemporary Research, 2(6), 112-121.

Vinney, C. (2019). Sutherland's differential association theory explained. Retrieved January 2019 from https://www.thoughtco.com

Wolfe, D., \& Hermanson, D. R. (2004). The fraud diamond: Considering four elements of fraud. The CPA Journal, 74(12), 38-42. https://doi.org/10.1016/S1361-3723(04)00065-X

\section{Appendix 1}

\section{Experience in occupational fraud detection schemes (OFDS)}

\section{OFDS}

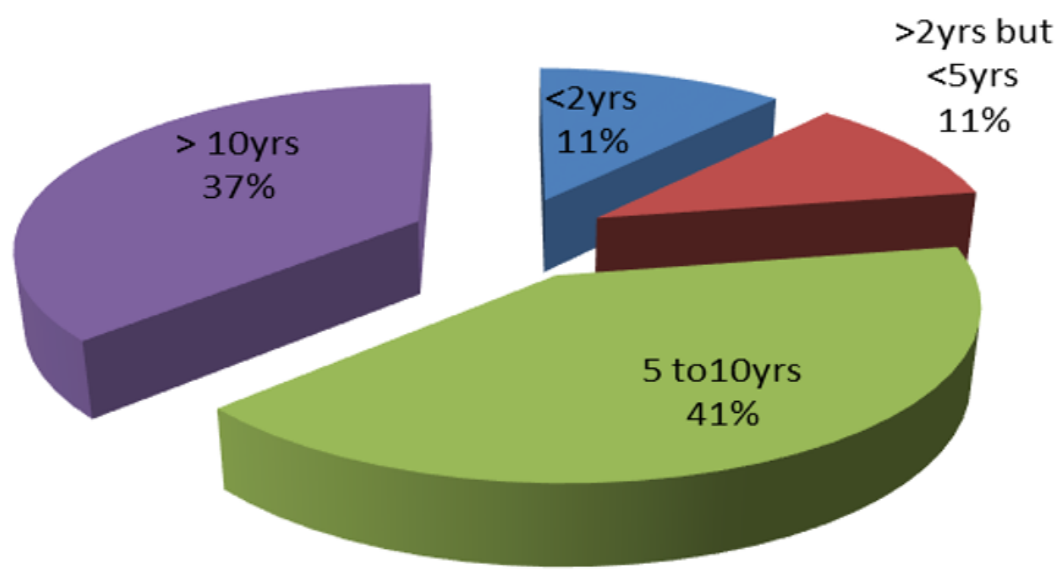




\section{Appendix 2}

Items on initial detection of occupational fraud

\begin{tabular}{|c|c|c|c|c|c|c|}
\hline $\begin{array}{lll}\begin{array}{l}\text { Occupational } \\
\text { schemes }\end{array} & \text { fraud } & \text { detection } \\
\end{array}$ & $\begin{array}{l}\text { Strongly } \\
\text { disagree }\end{array}$ & Disagree & $\begin{array}{l}\text { Un- } \\
\text { decided }\end{array}$ & Agree & $\begin{array}{l}\text { Strongly } \\
\text { disagree }\end{array}$ & TOTAL \\
\hline \multirow{2}{*}{ Surprise audit } & 0 & 2 & 8 & 79 & 14 & 103 \\
\hline & $0 \%$ & $1.9 \%$ & $7.8 \%$ & $76.7 \%$ & $13.6 \%$ & \\
\hline \multirow[t]{2}{*}{ Monitoring } & 1 & 10 & 15 & 31 & 46 & 103 \\
\hline & $1 \%$ & $9.7 \%$ & $14.6 \%$ & $30.1 \%$ & $44.7 \%$ & \\
\hline \multirow[t]{2}{*}{ Fair treatment of staff } & 12 & 15 & 14 & 21 & 30.1 & 103 \\
\hline & $21.4 \%$ & $14.6 \%$ & $13.6 \%$ & $20.4 \%$ & $30.1 \%$ & \\
\hline \multirow[t]{2}{*}{ Tips } & 1 & 15 & 25 & 42 & 19 & 102 \\
\hline & $1 \%$ & $14.6 \%$ & $24.3 \%$ & $40.8 \%$ & $18.4 \%$ & \\
\hline \multirow{2}{*}{ Notification by law enforcement } & 38 & 36 & 21 & 6 & 2 & 103 \\
\hline & $36.9 \%$ & $35 \%$ & $20.4 \%$ & $5.8 \%$ & $1.9 \%$ & \\
\hline \multirow{2}{*}{ Rotation of duties } & 3 & 9 & 31 & 34 & 24 & 101 \\
\hline & $2.9 \%$ & $8.7 \%$ & $30.1 \%$ & $33 \%$ & $23.3 \%$ & \\
\hline \multirow{2}{*}{ Abrogation of paid leave } & 1 & 6 & 13 & 32 & 51 & 103 \\
\hline & $1 \%$ & 5.8 & 12.6 & 31.1 & 49.5 & \\
\hline \multirow{2}{*}{ Surveillance/monitoring } & 3 & 2 & 10 & 43 & 45 & 103 \\
\hline & $2.9 \%$ & $1.9 \%$ & $9.7 \%$ & 41.7 & 43.7 & \\
\hline \multirow{2}{*}{ IT Controls } & 2 & 9 & 9 & 55 & 28 & 103 \\
\hline & $1.9 \%$ & $8.7 \%$ & $8.7 \%$ & $53.4 \%$ & $27.2 \%$ & \\
\hline \multirow{2}{*}{ By accident } & 10 & 34 & 10 & 26 & 23 & 103 \\
\hline & $9.7 \%$ & $33 \%$ & $9.7 \%$ & $25.2 \%$ & $22.3 \%$ & \\
\hline \multirow{2}{*}{ Confession } & 27 & 24 & 12 & 27 & & 103 \\
\hline & $26.2 \%$ & $23.3 \%$ & $11.7 \%$ & $26.2 \%$ & $12.6 \%$ & \\
\hline
\end{tabular}

\section{Copyrights}

Copyright for this article is retained by the author(s), with first publication rights granted to the journal.

This is an open-access article distributed under the terms and conditions of the Creative Commons Attribution license (http://creativecommons.org/licenses/by/4.0/). 